UDC 577.2

\title{
EFFECT OF MOLYBDENUM ON THE ACTIVITY OF MOLYBDOENZYMES
}

\author{
Iksat N.N., Zhangazin S.B., Madirov A.A., Omarov R.T. \\ Department of Biotechnology and Microbiology, L.N. Gumilyov Eurasian \\ National University \\ 13, Kazhymukan street, Nur-Sultan, 010000, Kazakhstan \\ nurguliksat@gmail.com
}

\begin{abstract}
The soil is a reservoir of various contaminants with heavy metals and has a strong cation exchange property. Among these heavy metals, molybdenum is an essential element that is required in small quantities for optimal plant growth and development. This useful heavy metal performs several biochemical and physiological tasks in plants and is also considered as an important component of various cellular enzymes and is actively involved in redox reactions. Mononuclear molybdenum-containing enzymes, as a rule, have a certain conserved metal center, coordinated by one or two pyranopterins. The pyranopterin fragment plays a key role in the properties of the metal site in the group of mononuclear enzymes of molybdenum with various functions: coordination; stabilization and modulation of the redox transitions of the center, acting as a redox buffer; and for redox regulation/compliance in a variety of catalytic reactions. The coordination sphere of the metal is equipped with oxygen and/or sulfur, selenium atoms in various forms. Tungsten is an antagonist of molybdenum and inhibits molybdoenzymes. In the current review we elaborately reviewed various studies regarding heavy metals - molybdenum and tungsten, their uptake mechanism, essential transporters, and also discuss about the destructive properties of heavy metals in response to their concentration.
\end{abstract}

Key words: molybdenum, molybdoenzyme, molybdenum cofactor, tungsten, xanthine dehydrogenase, aldehyde oxidase.

\section{INTRODUCTION}

Molybdenum (Mo) is an important trace element that occurs in nature in various chemical compounds and has a redox function, as evidenced by its extended oxidation state spectrum, ranging from II to VI among various forms and States of Mo oxidation. Although the content of Mo in the cell is low, its absorption requires an adequate and effective mechanism that ensures its constant supply. While bacteria mediate the uptake of molybdate using an ATP-bound cassette transporter [1], plants use two different transporters called Mot1 and Mot2 [2]. Animals lack Mot1, but Mot2 was first identified as the first vector in animal cells in 2011 [3].

The availability of Mo for plant growth strongly depends on the $\mathrm{pH}$ of the soil, the concentration of adsorbing oxides, the degree of water drainage, and the presence of organic compounds. Mo becomes more soluble and available to plants in alkaline soils, mainly in the form of anions such as $\mathrm{MoO}_{4}{ }^{2-}$. On the contrary, the availability 
of Mo decreases in acidic soils $(\mathrm{pH}<5.5)$, as the adsorption of anions in soil oxides increases [4]. When plants grow under conditions of Mo deficiency, number of different morphological changes occurs that inhibit plant growth. Most of these changes are associated with reduced activity of molybdenum enzymes.

The first experiments in the need for Mo growth by plants were demonstrated on tomatoes grown on a hydroponic system without Mo [5]. Plants grown under these conditions have developed characteristic phenotypes, such as leaf spotting, changes in leaf blade morphology.

The first recorded case of Mo deficiency in agriculture occurred on mixed pastures in the highlands of South Australia. Later, Walker noticed that plants grown on serpentine soils with Mo deficiency can be quickly saved by applying exogenous sodium molybdate directly to the soil or by infiltrating the leaves with this solution [6].

\section{DISCUSSION}

Mo itself is not biologically active, but is an integral part of an organic pterine complex called the molybdenum cofactor (MoCo). To create a biologically active cofactor of molybdenum, a Mo complex with a pterin compound must be formed. Thus, MoCo consists of a tricyclic pterin that coordinates Mo through a dithiol group in the third pyranocircle.

All Mo-dependent enzymes contain a pterin-type cofactor, with the exception of bacterial nitrogenase, in which a unique iron-molybdenum cofactor gives catalytic activity. MoCo occurs in two forms in eukaryotic cells, that differ in relation to Mo. In the first form, Mo is covalently bound to a conservative cysteine residue in The MoCo connective domain. In the second form, the third terminal sulfur ligand is bound to Mo, but in this variant, MoCo remains non-covalently bound to the corresponding protein (Figure 1) [7].

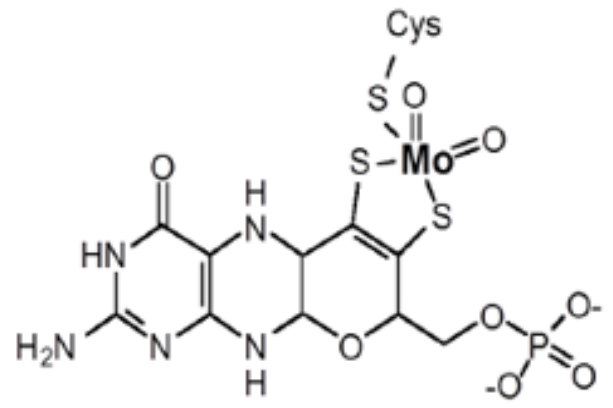

A<smiles>Nc1nc2c(c(=O)[nH]1)NC1C(SS(=O)(=O)O)=C(S(=O)(=O)O)C(COP(=O)(O)O)OC1N2</smiles>

B

A - the first form of Mo Co; B - the second form of MoCo.

Fig. 1. Structures of two eukaryotic MoCo types

In addition to Mo, the pterine cofactor is an integral part of the active site in both molybdenum and tungsten-containing enzymes. In eukaryotes, molybdopterin or pyranopterin has a structure with a terminal phosphate group on the pterin side chain, but in prokaryotes, the cofactor occurs in the form of CDP, GDP, ADP, and IDP (Figure 2). The conformation of pyranopterin correlates with protein folds that define 
the three main mononuclear families of molybdenum and tungsten enzymes, and that micro-regulation of the binding site controls the oxidation state of pyranopterin [8].<smiles>Nc1nc2c(c(=O)[nH]1)NC(/C(S)=C(/S)C(O)COO)CN2</smiles><smiles>NC1=C(S)C(CO[18O])OC2Nc3c(nc(N)[nH]c3=O)NC12</smiles><smiles>Nc1nc2c(c(=O)[nH]1)NC1C(=NC3OC(COP(=O)(O)OP(=O)(O)OC3OC3C(O)C(O)C3n3cnc4c(=O)[nH]c(N)nc43)C([Hg])=C1[SiH3])N2</smiles>

A - the proposed structure of the pterine cofactor [9].; B- the structure of the cofactor first discovered in the aldehyde oxidoreductase of $P$. Furiosus [10]; C - the structure of the pterine cofactor - guanosine - dinucleotide present in the reductase of $R$. sphaeroides DMSO[11].

Fig.2. The structure of the pterine cofactor.

Integration of Mo in MoCo in two variants allows placing Mo in the active center of the protein, thereby controlling its redox properties and aligning the pterin ring system for electron transfer into Mo or out of it [12].

The pathway of the Moco biosynthesis reaction, as well as the biosynthesis enzymes, are highly conserved and can be found in almost all prokaryotes and eukaryotes. These enzymes are designated in plants by the abbreviation for cofactor nitrate reductase and xanthine dehydrogenase (Cnx1-3 and 5-7). As shown in figure $3, \mathrm{Cnx} 2$ and $\mathrm{Cnx} 3$ catalyze the first stage by converting 5'-GTP to cyclic pyranopterin monophosphate inside mitochondria [13]. The resulting cPMP is exported to the cytosol by the ATM3 transporter [14] for introducing the dithiolene group by transferring two sulfur atoms forming molybdopterin (MPT). This second step of the reaction is catalyzed by MPT synthase, a heterotetramer with two large Cnx6 subunits and two small $\mathrm{Cnx} 7$ subunits. After sulfur transfer, the $\mathrm{Cnx} 7$ subunits must be resulfated using the MPT synthase Cnx5 sulfurase [15]. The Cnx1 mo insert catalyzes the last two stages of biosynthesis. Cnx 1 consists of a larger N-terminal domain of Cnx1E and a smaller C-terminal domain of Cnx1G. MPT is bound by the Cnx1G domain and is activated by adenylation, thereby forming MPT-AMP in the third step [16]. This intermediate is transferred to the Cnx1E domain, which releases AMP and inserts Mo derived from molybdate [17]. This required molybdate is imported by certain molybdate carriers [18]. 


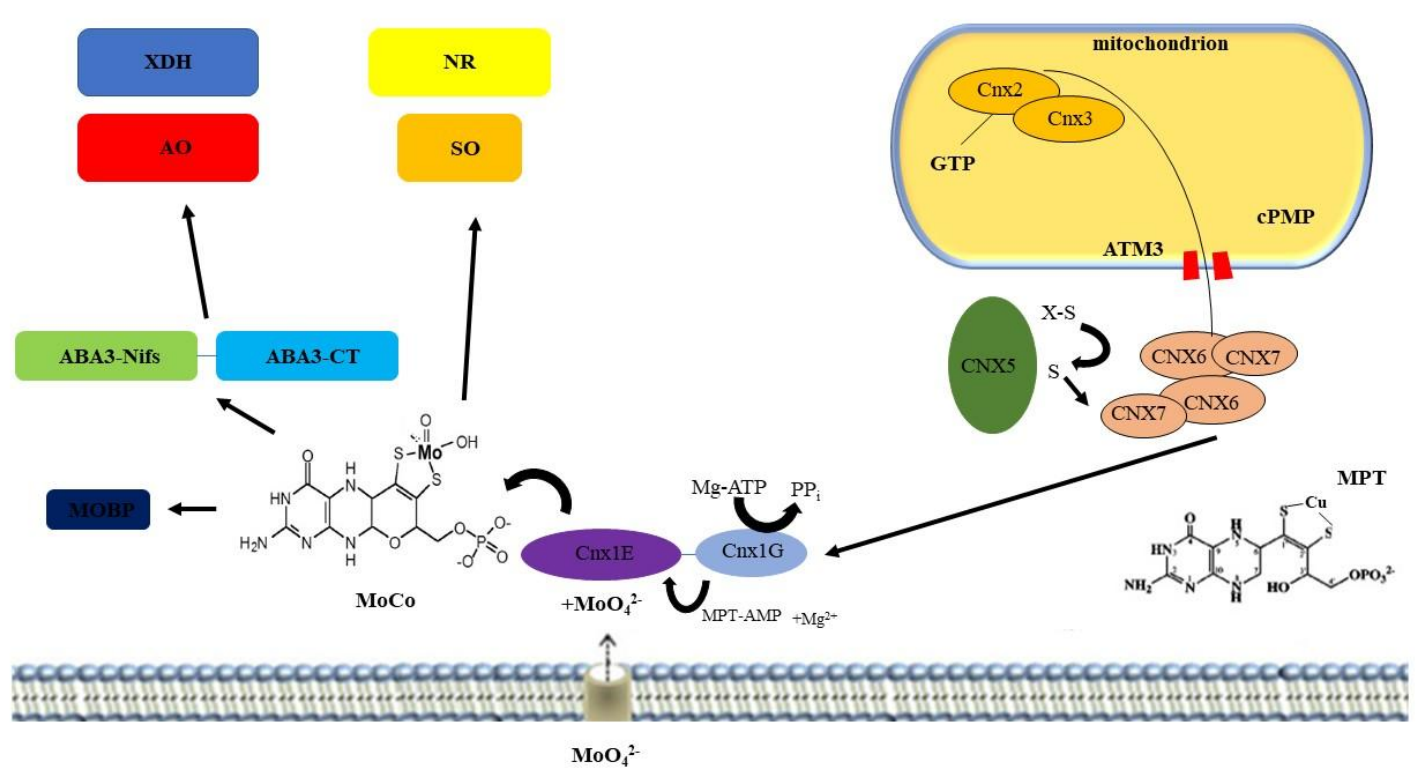

Fig.3. MoCo enzyme pathway with a four-step reaction catalyzed by $\mathrm{Cnx} 2$ and $\mathrm{Cnx} 3$ inside the mitochondria, as well as $\mathrm{Cnx} 6, \mathrm{Cnx} 7, \mathrm{Cnx} 5$ and $\mathrm{Cnx} 1$ in the cytosol. After biosynthesis, Moco is distributed both in families of Mo-enzymes and in MoCo-binding proteins

After the MoCo is synthesized, it is included in the composition of the different Mo-enzymes to fulfill their biological functions. About fifty Mo-dependent enzymes have been described, which play an important role in the nitrogen, carbon, and sulfur cycles in the biosphere [19]. Most of these enzymes are found exclusively in prokaryotes. One of the enzymes nitrate reductase (NR) is found only in plants and fungi, playing a key role in nitrogen assimilation, catalyzing the reduction of nitrate to nitrite. In addition to MoCo, NR has the integration of cytochrome b5 and FAD cofactor for the catalytic activity of the enzyme. So, electrons are transferred from $\mathrm{NAD}(\mathrm{P}) \mathrm{H}$ to FAD, and through the heme to the MoCo domain, where the active site is located, where the nitrate is reduced.

Plant molybdenum enzymes can be grouped into those involved in the assimilation and reduction of nitrogen - nitrate reductase (NR), nitrogenase; in purine catabolism - xanthine oxidase, xanthine dehydrogenase ( $\mathrm{XO}, \mathrm{XDH})$; in the synthesis of abscisic (ABC) and indole-3-acetic acids (IUC) - aldehyde oxidase (AO), as well as in the metabolism of sulfur - sulfitoxidase (SO). In addition, Mo-enzymes can be classified based on their interactions with MoCo: NR and SO contain a dioxo-Mo cofactor, and $\mathrm{AO}$ and $\mathrm{XDH}$ have a monooxo-Mo cofactor [20].

Xanthine oxidase and xanthine dehydrogenase are two different forms of the same enzyme. They catalyze the conversion of xanthine to uric acid in the catabolism of purine bases. Two enzymes differ in the chemical nature of the oxidizing substrate: $\mathrm{O}_{2}$ for $\mathrm{XO}, \mathrm{NAD}^{+}$for $\mathrm{XDH}$ [21]. CDG has been mainly studied in animals for 80 years [22]. In mammals, $\mathrm{XDH}$ can be converted to $\mathrm{XO}$ by post-translational modifications, thereby forming superoxide and hydrogen peroxide, which can be used as pathogenic inhibitors in infected cells [23]. In plant cells, however, XDH is not converted into any form and produces only superoxide [24]. XDH has a physiological function in the metabolism of ROS, the transmission of signals of which is manifested in the stress associated with drought, the relationship of plants and pathogens, hypersensitivity [25] and aging [26]. Arabidopsis has two highly homologous XDH genes (XDH1 and XDH2). XDH1 has a controversial role in ROS metabolism in A. thaliana: it produces hydrogen peroxide in leaf epidermal cells as a weapon against microorganisms, whereas it produces uric acid in leaf mesophyll 
cells, which recycles $\mathrm{H} 2 \mathrm{O} 2$ in chloroplasts. Based on these data, it is likely that the different availability of the substrate in epidermal cells (NAD/O2) and mesophyll cells (xanthin/NAD+) determines the opposite abilities of XDH1 in ROS metabolism. Since the $\mathrm{XDH}$ nucleotide sequence is highly conserved, it can be assumed that this phenomenon is present in other plants as well.

According to some data , AO has a high sequence identity with XDH [27], indicating that $\mathrm{AO}$ is the result of an ancient recurrent duplication of the $\mathrm{XDH}$ gene. We compared the AO and XDH sequences in A. thaliana and obtained only $48 \%$ identity (Figure 4).

\begin{tabular}{|c|c|c|c|}
\hline 536 bits & $2(1381)$ & 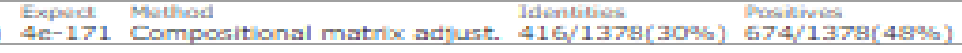 & $141 / 1378(10 \%)$ \\
\hline $\begin{array}{l}\text { Qucry } \\
\text { Sbjet }\end{array}$ & $\begin{array}{l}36 \\
42\end{array}$ & 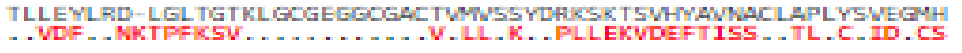 & Iอี \\
\hline Qucry & 95 & 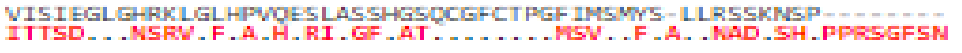 & $\begin{array}{l}145 \\
165\end{array}$ \\
\hline Sucry & $\begin{array}{l}146 \\
162\end{array}$ & 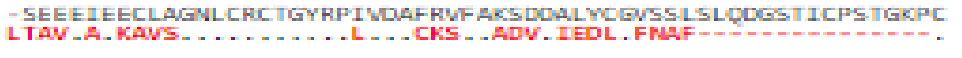 & $\frac{284}{286}$ \\
\hline Qucry & $\begin{array}{l}285 \\
287\end{array}$ & $\begin{array}{l}\text { SCGSKITNEVASCNEDFFOS ISYSDIDGAKYTDKEL IFPPELLL LRKL TPLKL RGGNGGITW } \\
\text { KK..- }\end{array}$ & 254 \\
\hline Sucry & 265 & 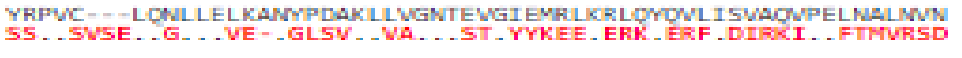 & $\begin{array}{l}321 \\
312\end{array}$ \\
\hline $\begin{array}{l}\text { Qucry } \\
\text { Sbjet }\end{array}$ & $\begin{array}{l}322 \\
313\end{array}$ & 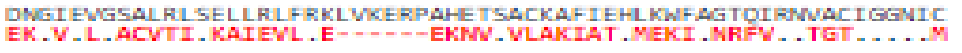 & $\begin{array}{l}381 \\
366\end{array}$ \\
\hline Qucry & $\begin{array}{l}382 \\
367\end{array}$ & 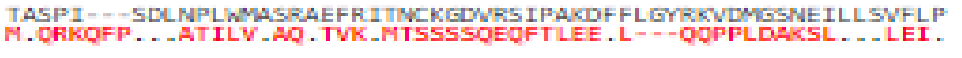 & 438 \\
\hline gucry & 4239 & 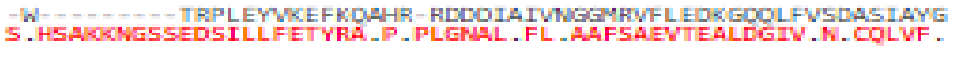 & 487 \\
\hline Qucry & 488 & 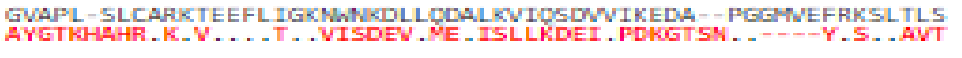 & 539 \\
\hline $\begin{array}{l}\text { Qucry } \\
\text { Sbjet }\end{array}$ & $\begin{array}{l}545 \\
540\end{array}$ & 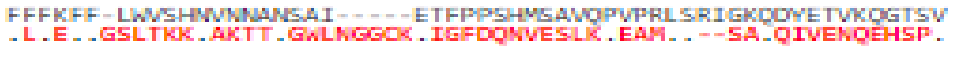 & $\begin{array}{l}598 \\
597\end{array}$ \\
\hline $\begin{array}{l}\text { Qucry } \\
\text { Sbjet }\end{array}$ & $\begin{array}{l}599 \\
598\end{array}$ & 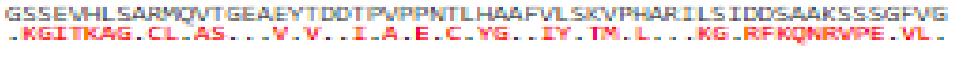 & $\begin{array}{l}658 \\
657\end{array}$ \\
\hline $\begin{array}{l}\text { Qucry } \\
\text { Sbjet }\end{array}$ & $\begin{array}{l}659 \\
658\end{array}$ & 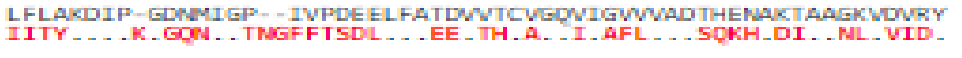 & 715 \\
\hline Qucry & 716 & 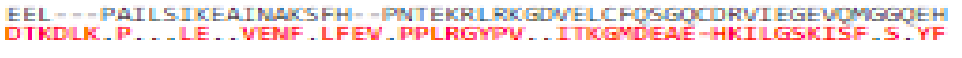 & 779 \\
\hline $\begin{array}{l}\text { Qucry } \\
\text { Sbjet }\end{array}$ & 777 & 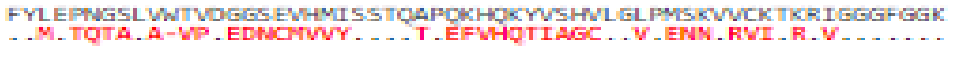 & $\begin{array}{l}839 \\
835\end{array}$ \\
\hline Oucry & $\begin{array}{l}831 \\
836\end{array}$ & 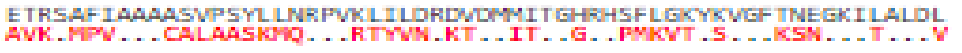 & $\begin{array}{l}899 \\
895\end{array}$ \\
\hline Sucry & $\begin{array}{l}891 \\
896\end{array}$ & 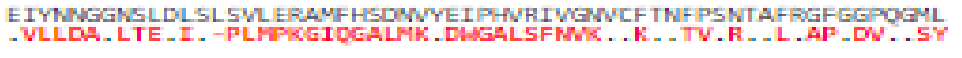 & $\begin{array}{l}950 \\
954\end{array}$ \\
\hline $\begin{array}{l}\text { Qucry } \\
\text { Sbjet }\end{array}$ & $\begin{array}{l}951 \\
955\end{array}$ & 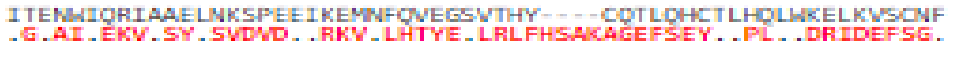 & $\begin{array}{l}1096 \\
1014\end{array}$ \\
\hline $\begin{array}{l}\text { Qucry } \\
\text { Sbjet }\end{array}$ & $\begin{array}{l}1 \text { eer } \\
1815\end{array}$ & 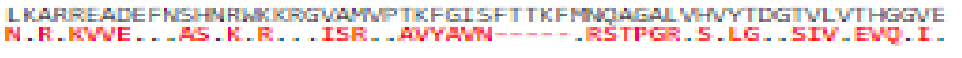 & $\begin{array}{l}1066 \\
1869\end{array}$ \\
\hline $\begin{array}{l}\text { gucry } \\
\text { Sbjet }\end{array}$ & $\begin{array}{l}1867 \\
1070\end{array}$ & 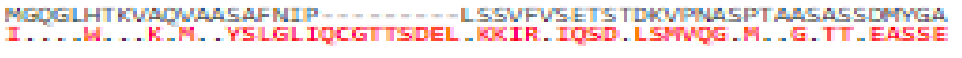 & $\begin{array}{l}1117 \\
1129\end{array}$ \\
\hline Qucry & $\begin{array}{l}1118 \\
1130\end{array}$ & 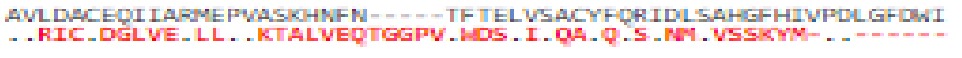 & $\begin{array}{l}1172 \\
1182\end{array}$ \\
\hline Qucry & $\begin{array}{l}1173 \\
1183\end{array}$ & 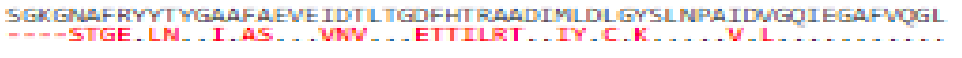 & $\begin{array}{l}1232 \\
1238\end{array}$ \\
\hline $\begin{array}{l}\text { Qucry } \\
\text { Sbjet }\end{array}$ & $\begin{array}{l}1233 \\
1239\end{array}$ & 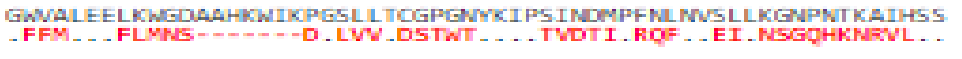 & $\begin{array}{l}1292 \\
1291\end{array}$ \\
\hline $\begin{array}{l}\text { Qucry } \\
\text { Sbjet }\end{array}$ & $\begin{array}{l}1293 \\
1292\end{array}$ & 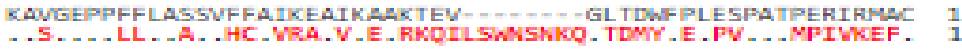 & 1342 \\
\hline
\end{tabular}

Fig.4. Alignment of $\mathrm{AO}$ and XDH sequences in A.thaliana (NCBI BLAST)

It was found that the most notable characteristics that distinguish $\mathrm{AO}$ from $\mathrm{XDH}$ enzymes relate to substrate binding to the Mo center and binding of the physiological electron acceptor [28]. AO enzymes are strict oxidases that cannot bind NAD and use exclusively molecular oxygen as an electron acceptor. When transferring the electrons obtained from the substrate to molecular oxygen, the plant $\mathrm{AO}$ generates hydrogen peroxide.

MoCo-dependent AO enzyme involved in the synthesis of phytohormones 
ABA and IAA. It is the last to catalyze the conversion of indole-3acetaldehyde to IAA, as well as the oxidation of abscisic aldehyde to ABA. Mutations in the $\mathrm{AO}$ apoprotein or in enzymes involved in the synthesis of MoCo and its activation disrupt the synthesis of ABA [29]. Low levels of ABA lead to excessive transpiration due to loss of control of stomatal functions, changes in the protective properties of plants [19]. It has been shown that ABA-deficient mutants (flacca, ABA3) that have weak phenotypes are destroyed at The MoCo activation stage [30].

There is evidence that levels of the AAO3 protein in A. thaliana are regulated by ubiquitin-dependent degradation via the $26 \mathrm{~S}$ proteasome to prevent premature aging by accumulating $\mathrm{ABA}$ [31]. This suggests that $\mathrm{ABA}$-synthesizing $\mathrm{AO}$ proteins also play a critical role during the onset of aging, which requires strict control of AO and ABA levels. The physiological role of animal AO is still unknown, although it can participate in the oxidation of a wide range of endogenous substrates, such as neurotransmitter vitamins. Different concentrations of molybdenum can affect the activity of $\mathrm{AO}$ in leaves and roots in barley, thus differentially affecting the growth and development of the plant [32].

Replacing molybdenum with tungsten in MoCo-enzymes usually leads to a loss or decrease in the activity of one or another enzyme [33]. In experiments with the synthesis of ABA, it was shown that tungsten was used as an inhibitor of ABA formation in cell-free systems at concentrations of $0.1 \mathrm{mM}$ [34] and Galium seedlings $(0.5 \mathrm{mM}$ [35]. But there is evidence that at a concentration of $0.1 \mathrm{mM}$, tungsten in daffodils is ineffective [36].

Tungsten as an inhibitor of the activity of Mo-hydroxylases. In some pro and eukaryotes, tungsten (W) easily replaces Mo in Mo-enzymes; in this case, inactive tungsten analogues of Mo enzymes are formed. Thus, the formation of such analogues in NR was shown in plants [37] fungi [38], algae [39]. The substitution was found in animal cells for sulfitoxidase and xanthine oxidase [40].

Inactivation of Mo-enzymes by tungsten is reversible; for instance, when transferring bacterial $\mathrm{W}$-cells to a medium containing molybdenum, NR is converted to the active form of Mo, and inactive tungsten nitrate reductase isolated from Escherichia coli W-cells can restore the activity of NR defective in the cofactor of molybdenum fungus in neurospora crassa thread mutant 1 in the presence of $1 \mathrm{mM}$ sodium molybdate [41]. In all the above-mentioned studies, tungsten could only be incorporated into Mo-enzymes during in vivo. Only in the case of animal sulfitoxidase it was possible to replace tungsten with molybdenum in vitro and thus $\mathrm{W}$-containing the enzyme [42].

More than $35 \%$ of plant nitrate reductase (NR) is in the form of a holoenzyme containing the metal-reducing cofactor molybdenum, which preserves the ability to coordinate metals. Namely this part of NR containing molybdenum can be "stabilized", that is, protected from proteolysis and other processes that inactivate enzymes, by tungsten. Studies of spinach and cauliflower have shown that NR remains inactive after the inclusion of tungsten, where tungsten can be replaced by molybdenum when trace amounts of the latter appear in the medium [43]. In this way, the tungsten-stabilized enzyme is activated.

The effect of stabilizing tungsten can be significant: for instance, the growth of cauliflower on a medium containing equimolar concentrations of tungsten and molybdenum $(0.005 \mathrm{mcg} / \mathrm{l})$ caused an increase in NR activity by $20 \%$, and the growth of the plant was greatly accelerated. Hypersynthesis of the NR apoprotein of tobacco is another possible cause of an increase in the NR activity of plants growing on an environment with equimolar concentrations of tungsten and molybdenum [44]. 
A significant difference between $\mathrm{W}$-enzymes and their Mo analogues is that the former is expressed constitutively in most of the studied microorganisms, whereas Mo analogues are induced only in the presence of molybdenum [45]. In addition, the presence of the same labile complex - a molybdenum cofactor that can function with both molybdenum, tungsten, and so on - in various organisms from the earliest hyperthermophilic archaea to humans indicates the importance of Mo and Wcontaining enzymes in the evolutionary process. It is assumed that before the appearance of molecular oxygen formed during photosynthesis, molybdenum and tungsten were present on Earth as sulfides (WS2 and MoS2), rather than oxyanions (MoO4 and WO4). Since tungsten sulfide is better soluble in water than molybdenum sulfide, it is assumed that in the pre-oxygen era, tungsten might have been more accessible to organisms than molybdenum. This assumption is consistent with the fact that "true W enzymes" are found in strict anaerobic microorganisms, although there is an exception - FDH in methylotrophic bacteria [46].

Since W possesses certain chemical properties with an indispensable plant microelement molybdenum, it is proposed to inhibit the enzymatic activity of molybdenum by replacing the Mo ion associated with the cofactor. Recent studies show that W, like other heavy metals, also has a toxic effect on its own. Studies on the effect of $\mathrm{W}$ on soybean growth and metabolism (Glycine max) showed a picture of tungsten stress when high tungsten concentrations inhibited nitrate reductase activity, thereby lowering the level of nitrogen in plants. This is not surprising, since it was shown that due to competition with molybdenum as an enzymatic co-factor, tungsten leads to a decrease in NR activity, but does not inhibit its synthesis [47]. Harper and Nicholas found that while nitrate reductase activity of $\mathrm{N}$ was fed by soybean plants $(6 \mathrm{mM} \mathrm{KNO} \mathrm{3)}$ continuously decreased with increasing tungsten levels to $8.6 \%$ at $0.4 \mathrm{mM}$ compared to control plants, a decrease in acetylene showed 3 -fold increase between control and $0.4 \mathrm{~mm}$. The authors suggested that the observed patterns, along with an increase in nodule biomass, were the result of inhibition of the NO-33 W metabolism, leading to an increase in the C:N ratio [48]. Such compensation for NR activity due to increased nodulation and increased $\mathrm{N} 2$ fixation activity of soybean was also observed in one of the studies on the bioavailability, speciation, and phytotoxicity of tungsten in soil.

In contrast to nitrate reductase, the effect of tungsten on bacterial nitrogen fixation (BNF) via nitrogenase, apparently, is not explained simply by inhibition of the catalytic function of the enzyme by replacing Mo with $\mathrm{W}$, since $\mathrm{N} 2$ fixation activity (mg $\mathrm{N}$ is fixed, $\mathrm{g}-1 \mathrm{dwt}$ nodule) from a smaller number of nodules formed at high $\mathrm{W}$ was not completely inhibited by tungsten $(\sim 55 \%$ activity remained at 0.5 $\mathrm{mM} \mathrm{W}$ ). Accordingly, in some studies, indices of active nitrogenase were found even in the presence of tungsten, and that the inhibitory effect of tungsten on nitrogenase is more pronounced in conditions of Mo deficiency [49].

As has already been shown that $\mathrm{N} 2$ fixation, the activity of $\mathrm{N} 2$ fixing bacteria decreases or is suppressed in the presence of tungsten [49], although some exchange experiments show that bacterial Mo-nitrogenase can be functional when Mo is replaced by W [50]. The symbiotic bacteria B. japonicum Harper and Nicholas [47] even showed an increase in acetylene reduction in soybeans grown by $0.4 \mathrm{mM}$ W. As for endogenous plant molybdosimes, previous work suggests that replacing molybdenum in Mo-MRI with tungsten causes inhibition the catalytic function of the enzyme. According to Xiong et al. [46] this substitution probably not only affects nitrate reduction and nitrite oxide levels, but, like other heavy metals, leads to oxidative stress by increasing ROS production by inhibiting ABA biosynthesis, purine metabolism, and sulfur metabolism; however, a comprehensive assessment of 
W-metabolic changes has not yet been performed. Most likely, the toxicity of W depends on the body and the dose used.

For development and ability to resist pathogens, plants need nutrients. The increased demand for micronutrients can be explained by their importance for metabolic processes specific for molybdenum, since there is a suggested relationship between the metabolism of molybdenum, copper and iron. Copper, as well as iron, is involved in the MoCo biosynthesis, since some molybdenum enzymes require iron prosthetic groups, and copper is necessary for the formation of MoCo intermediates. In order for the plant to continue nitrogen metabolism, the production of NR apoenzymes is required and, therefore, enhanced assimilation of $\mathrm{Fe}, \mathrm{Cu}$ and $\mathrm{Mo}$. Therefore, the absence of active NR in combination with increased assimilation of Fe, $\mathrm{Cu}$, and Mo indicates impaired NR function, and not NR biosynthesis itself [47]. A similar increase in tungsten, caused by the growth of shoots of Mo, roots, and nodules, was also observed when soybeans were grown on calcareous soils sown with growing concentrations of metallic W. This is consistent with Strigul et al. [49], who discovered that the presence of tungsten promotes hyperaccumulation of molybdenum and vice versa. Possible changes in the level of nutrients and changes in the catalytic activity of molybdioenzymes caused by $\mathrm{W}$ can be caused by (1) competition for absorption through the same carriers as other anions (phosphate, sulfate, molybdate), (2) inhibition of absorption due to reduced growth roots, (3) decreased nutrient availability due to tungsten polymerization (especially $\mathrm{P}$ and $\mathrm{S}$ ) in the soil solution and / or in the acidic parts of the cell, such as vacuole.

\section{CONCLUSION}

It is known that transporters such as Mot 1.3 introduce molybdate into cells infected with rhizobia, as well as into uninfected cells within the nodule. This raises the question of why uninfected cells need molybdenum. Possible explanations might be that they are prepared in the event of infection, that they buffer or store molybdenum for later use, or that this molybdenum is required for the synthesis of active Moco-dependent enzymes in these cells. Many questions about MoCo remain unanswered: what factors influence the inclusion of tungsten instead of molybdenum in some enzymes? The answer may reflect bioavailability considerations, but there are also chemical differences between Mo and $\mathrm{W}$, such as the relative complexity of tungsten reduction to the $\mathrm{W}$ (IV) state and the increased bond strength of the $\mathrm{W}$ (VI) complexes, which may be of importance.

The use of tungsten as an inhibitor of the activity of Mo-hydroxylases will allow us to find evidence of the involvement (or not) of enzymes in resistance to phytopathogens, such as viruses, bacteria and fungi.

\section{Acknowledgements}

This work was supported by the Ministry of Education and Science of the Republic of Kazakhstan (grant AP05135013 «The involvement of ROS producing Mo-enzymes in root development and stress tolerance of plants»).

\section{REFERENCES}

1. Maupin-Furlow J. A. [et al.]. Genetic analysis of the modABCD (molybdate transport) operon of Escherichia coli. Journal of bacteriology, 1995, vol. 177, no. 17, pp. 4851-4856. 
2. Tejada-Jimenez M. [et al.]. A high-affinity molybdate transporter in eukaryotes Proceedings of the National Academy of Sciences, 2007, vol. 104, no. 50, pp. 2012620130.

3. Tejada-Jimenez M., Galvan A., Fernandez E. Algae and humans share a molybdate transporter. Proceedings of the National Academy of Sciences, 2011, vol. 108, no. 16, pp. 6420-6425.

4. Wichard T. [et al.]. Storage and bioavailability of molybdenum in soils increased by organic matter complexation. Nature Geoscience, 2009, vol.2, no. 9, pp. 625-629.

5. Arnon D. I. Molybdenum as an essential element for higher plants. Plant physiology, 1939 , vol.14, no. 3, pp. 599-602. https://doi.org/10.1104/pp.14.3.599

6. Walker R.B. Molybdenum Deficiency in Serpentine Barren Soils. Science, New Series, 1948, vol. 108, no. 2809, pp. 473-475.

7. Schwarz G., Mendel R. R. Molybdenum cofactor biosynthesis and molybdenum enzymes. Annual Review of Plant Biology, 2006. vol.57, no. 1, pp. 623-647.

8. Rothery R. A. [et al.]. Pyranopterin conformation defines the function of molybdenum and tungsten enzymes. Proceedings of the National Academy of Sciences of the United States of America, 2012, vol.109, no. 37, pp. 14773-14778.

9. Rajagopalan K. V., Johnson Jean L. The Pterin Molybdenum Cofactors. The Journal of Biological Chemistry, 1992, vol. 267, no.15, pp.10199-10202.

10. Chan M. K. [et al.]. Structure of a Hyperthermophilic Tungstopterin Enzyme, Aldehyde Ferredoxin Oxidoreductase. Science, New Series, 1995, vol. 267, no. 5203, pp. 1463-1469.

11. Fischer B. [et al.]. Models for the Active Center of Pterin-Containing Molybdenum Enzymes: Crystal structure of a molybdenum complex with sulfur and pterin ligands. Helvetica Chimica Acta, 1997, vol.80, no. 1, pp. 103-110.

12. Schwarz G., Mendel R. R., Ribbe M. W. Molybdenum cofactors, enzymes and pathways. Nature, 2009, vol. 460, no. 7257, pp. 839-847.

13. Havemeyer A., Bittner F., Wollers S., Mendel R., Kunze T., Clement B. Identification of the Missing Component in the Mitochondrial Benzamidoxime Prodrug-converting System as a Novel Molybdenum Enzyme. The journal of biological chemistry, 2006, vol. 281, no. 46, pp. 34796-34802.

14. Teschner J., Lachmann N., Schulze J., Geisler M., Selbach K., Santamaria-Araujo J., Balk J., Mendel R.R., Bittner F. A Novel Role for Arabidopsis Mitochondrial ABC Transporter ATM3 in Molybdenum Cofactor Biosynthesis. The Plant Cell, 2010, vol. 22, pp. 468-480.

15. Matthies A., Rajagopalan K. V., Mendel Ralf R. and Leimkuhler S. Evidence for the physiological role of a rhodanese-like protein for the biosynthesis of the molybdenum cofactor in humans. PNAS, 2004, vol. 101, no. 16, pp. 5946-5951. doi/10.1073/pnas.0308191101.

16. Kuper J. [et al.]. The active site of the molybdenum cofactor biosynthetic protein domain Cnx1G. Archives of Biochemistry and Biophysics, 2003, pp. 36-46, doi:10.1016/S0003-9861(02)00714-2.

17. Angel Llamas, Tanja Otte, Gerd Multhaup, Ralf R. Mendel and Guenter Schwarz. The Mechanism of Nucleotide-assisted Molybdenum Insertion into Molybdopterin: A novel route toward metal cofactor assembly. J. Biol. Chem. 2006, 281, pp. 1834318350, doi: 10.1074/jbc.M601415200.

18. Gasber A. [et al.]. Identification of an Arabidopsis solute carrier critical for intracellular transport and inter-organ allocation of molybdate. Plant Biology, 2011, pp. 710-718, doi:10.1111/j.1438-8677.2011.00448.x.

19. Mendel R. R. Molybdoenzymes and molybdenum cofactor in plants. Journal of Experimental Botany, 2002, vol.53, no. 375, pp. 1689-1698. 
20. Mendel R. R. Biology of the molybdenum cofactor. Journal of Experimental Botany, 2007, vol. 58, no. 9, pp. 2289-2296.

21. Turner N. A., Bray R. C., Diakun G. P. Information from e.x.a.f.s. spectroscopy on the structures of different forms of molybdenum in xanthine oxidase and the catalytic mechanism of the enzyme. Biochemical Journal, 1989, vol.260, no. 2, pp. 563-571.

22. Vorbach C., Harrison R., Capecchi M. R. Xanthine oxidoreductase is central to the evolution and function of the innate immune system. Trends in Immunology, 2003, vol.24, no. 9, pp. 512-517.

23. Nishino T. [et al]. Mammalian xanthine oxidoreductase - mechanism of transition from xanthine dehydrogenase to xanthine oxidase: Mammalian xanthine oxidoreductase. FEBS Journal, 2008, vol. 275, no. 13, pp. 3278-3289.

24. Yesbergenova Z. [et al]. The plant Mo-hydroxylases aldehyde oxidase and xanthine dehydrogenase have distinct reactive oxygen species signatures and are induced by drought and abscisic acid: ROS production by plant Mo-hydroxylases. The Plant Journal, 2005, vol. 42, no. 6, pp. 862-876.

25. Montalbini P., Della Torre G. Evidence of a two-fold mechanism responsible for the inhibition by allopurinol of the hypersensitive response induced in tobacco by tobacco necrosis virus. Physiological and Molecular Plant Pathology, 1996, vol.48, no. 4, pp. 273-287.

26. Pastori G. M., Rio L. A. del Natural Senescence of Pea Leaves (An Activated Oxygen-Mediated Function for Peroxisomes). Plant Physiology, 1997, vol.113, no. 2, pp. 411-418.

27. Rodriguez-Trelles F., Tarrio R., Ayala F. J. Convergent neofunctionalization by positive Darwinian selection after ancient recurrent duplications of the xanthine dehydrogenase gene. Proceedings of the National Academy of Sciences, 2003, vol.100, no. 23, pp. 13413-13417.

28. Seo M. [et al.]. Abscisic aldehyde oxidase in leaves of Arabidopsis thaliana. The Plant Journal, 2000, vol. 23, no. 4, pp. 481-488.

29. Sagi M., Scazzocchio C., Fluhr R. The absence of molybdenum cofactor sulfuration is the primary cause of the flacca phenotype in tomato plants: MoCo sulfurase in flacca tomato mutant. The Plant Journal, 2002, vol. 31, no. 3, pp. 305317.

30. Drechsel G., Raab S., Hoth S. Arabidopsis zinc-finger protein 2 is a negative regulator of ABA signaling during seed germination. Journal of Plant Physiology, 2010, vol. 167, no. 16, pp. 1418-1421.

31. Bittner F. Molybdenum metabolism in plants and crosstalk to iron. Frontiers in Plant Science, 2014, vol. 5, no. 28. doi: 10.3389/fpls.2014.00028.

32. Batyrshina Z. [et al.]. Differential influence of molybdenum and tungsten on the growth of barley seedlings and the activity of aldehyde oxidase under salinity. Journal of Plant Physiology, 2018, no. 228, pp. 189-196.

33. W.R. Hagen and A.E Arendsen. The Bio-lnorganic Chemistry of Tungsten. Structure and Bonding, vol. 90, 1998, pp. 162-191.

34. Lee H.-S., Milborrow B. V. Endogenous Biosynthetic Precursors of (+)-Abscisic Acid. V. Inhibition by Tungstate and its Removal by Cinchonine shows that Xanthoxal is Oxidised by a Molybdo-Aldehyde Oxidase. Functional Plant Biology, 1997, vol. 24, no.6, p. 727.

35. Hauke Hansen and Klaus Grossmann. Auxin-Induced Ethylene Triggers Abscisic Acid Biosynthesis and Growth Inhibition. Plant Physiol., vol. 124, 2000, pp. 14371448 .

36. Zeller M., Hunter A.D. Crystal structure of molybdenum and tungsten transbis(dinitrogen)-bis\{di(p-ethylbenzene)phosphino)ethane $\}$ toluene solvate, $\mathrm{M}\left(\mathrm{C}_{34} \mathrm{H}_{40} \mathrm{P}_{2}\right)_{2}\left(\mathrm{~N}_{2}\right)_{2} * \mathrm{C}_{7} \mathrm{H}_{8}(\mathrm{M}=\mathrm{Mo}, \mathrm{W})$. Kristallogr. NCS, 2004, 219, pp. 249-254. 
37. Maurya A. K., Rani A. Nitric Oxide (NO) and Physio-biochemical Adaptation in Plants Against Stress. Springer Singapore, 2017, pp. 347-386.

38. Preiner J. [et al.]. Molecular Mechanisms of Tungsten Toxicity Differ for Glycine max Depending on Nitrogen Regime. Frontiers in Plant Science, 2019, vol. 10, p. 367.

39. Vega J. M. Nitrogen and Sulfur Metabolism in Microalgae and Plants: 50 Years of Research Progress in Botany. Springer International Publishing, 2018, pp. 1-40.

40. Habib U., Hoffman M. Effect of molybdenum and tungsten on the reduction of nitrate in nitrate reductase, a DFT study. Chemistry Central Journal, 2017, vol.11, no. 1, p. 35 .

41. Nancy Klein Amy, Reginald H. Garrett. Immunoelectrophoretic Determination of Nitrate Reductase in Neurospora crassa I. Analytical biochemistry, 1979, pp. 97-107

42. Jones H.P. [et al.]. In vitro reconstitution of demolybdosulfite oxidase by molybdate. The Journal of Biological Chemistry, 1977, no.14, pp. 4988-4993.

43. Kumar A., Aery N. C. Effect of tungsten on growth, biochemical constituents, molybdenum and tungsten contents in wheat. Plant, Soil and Environment, 2011, vol. 57, no. 11, pp. 519-525.

44. Chamizo-Ampudia A. [et al.]. Nitrate Reductase Regulates Plant Nitric Oxide Homeostasis. Trends in Plant Science, 2017, vol. 22, no. 2, pp. 163-174.

45. Hochheimer A. [et al.]. The Molybdenum Formylmethanofuran Dehydrogenase Operon and the Tungsten Formylmethanofuran Dehydrogenase Operon from Methanobacterium Thermoautotrophicum. Structures and Transcriptional Regulation. European Journal of Biochemistry, 1996, vol. 242, no. 1, pp. 156-162.

46. Cho S. [et al.]. Stimulation of cell growth by addition of tungsten in batch culture of a methanotrophic bacterium, Methylomicrobium alcaliphilum $20 \mathrm{Z}$ on methane and methanol. Journal of Biotechnology, 2020, vol. 309, pp. 81-84.

47. Jie Xiong, Guanfu Fu, Yongjie Yang, Cheng Zhu and Longxing Tao. Tungstate: is it really a specific nitrate reductase inhibitor in plant nitric oxide research? Journal of Experimental Botany, 2011, pp. 1-9, doi:10.1093/jxb/err268.

48. James E. Harper and Joseph C. Nicholas. Nitrogen Metabolism of Soybeans. Plant Physiol., 1978, pp. 662-664.

49. Nikolay Strigul, Agamemnon Koutsospyros, Christos Christodoulatos. Tungsten speciation and toxicity: Acute toxicity of mono- and poly-tungstates to fish. Ecotoxicology and Environmental Safety, 2010, pp. 164-171.

50. Loes E. Bevers, Peter-Leon Hagedoorn, Wilfred R. Hagen. The bioinorganic chemistry of tungsten. Coordination Chemistry Reviews, 2009, pp. 269-290.

\title{
МОЛИБДОФЕРМЕНТТЕРДІН БЕЛСЕНДІЛІГІНЕ МОЛИБДЕННІН ӘСЕРІ
}

\author{
Иқсат Н.Н., Жангазин С.Б., Мадиров А.А., Омаров Р.Т. \\ Биотехнология және микробиология кафедрасы, Л. Н. Гумилев атындагы \\ Еуразия ұлттық университеті \\ Қажымұқ̧ан көшесі, 13, Нұр-Сұлтан, 010000, Қазақсстан \\ nurguliksat@gmail.com
}

\section{ТYЙІН}

Топырақ әр түрлі ауыр металдармен ластанады және үлкен катиондық алмасушы сипатқа ие. Осы ауыр металдардың ішінде 
молибден өсімдіктердің оптимальды өсуі мен даумына аз мөлшерде қажетті маңызды элемент болып табылады. Бұл пайдалы ауыр металл өсімдіктерде біршама биохимиялық және физиологиялық міндеттерді атқарады және де тотығу-тотықсыздану реакцияларына белсенді қатысып, жасушалық ферменттердің кұрамдас бөлігі ретінде қарастырылады. Мононуклеарлы молибденқұрамды ферменттер, әдетте, бір немесе екі пираноптеринмен үйлестірілетін белгілі бір консервативті металдық орталыққа ие болады. Пираноптерин фрагменті үйлестіру; тотықтырғыш буфері ретінде қызмет ететін орталықтың тотықтырғыштотықсыздандырғыш өтулерін тұрақтандыру және модуляциялау; және әр түрлі каталитикалық реакциялардағы тотығу-тотықсызданудың реттелуі/сәйкес келуі сияқты әр түрлі қызмет атқаратын бірядролы молибденқұрамды ферменттер қасиетінде маңызды рөл атқарады. Металдың координациялық сферасы әр түрлі формадағы оттек және/немесе күкірт, селеннің атомдарымен қамтамасыздандырылған. Вольфрам молибденнің антогонисті болып табылады және молибдоферменттерді ингибирлейді. Біз осы әдеби шолуда молибден және вольфрам ауыр металдарына, олардың сіңірілу механизмі, негізгі тасымалдаушыларына қатысты әр түрлі зерттеулерді, сонымен қатар концентрацияға байланысты ауыр металдардың кері қасиеттерін егжей тегжейлі талқыладық.

Негізгі сөздер: молибден, молибдофермент, молибденді кофактор, вольфрам, ксантиндегидрогеназа, альдегидоксидаза.

\section{ВЛИЯНИЕ МОЛИБДЕНА НА АКТИВНОСТЬ МОЛИБДОФЕРМЕНТОВ}

Иқсат Н.Н., Жангазин С.Б., Мадиров А.А., Омаров Р.Т.

Кафедра биотехнологии и микробиологии, Евразийский национальный университет имени Л. Н. Гумилева

ул. Қажымұқана, 13, Нур-Султан, 010000, Казахстан

nurguliksat@gmail.com

\section{АБСТРАКТ}

Почва является резервуаром различных загрязнителей, содержащих тяжелые металламы, и обладает сильной катионообменной способностью. Молибден является важным элементом, который требуется в небольших количествах для оптимального роста и развития растений. Этот металл выполняет несколько биохимических и физиологических задач в растениях, а также рассматривается как важный компонент различных клеточных ферментов и активно участвует в окислительновосстановительных реакциях. Мононуклеарные молибденсодержащие ферменты, как правило, имеют определенный консервативный металлический центр, координируемый одним или двумя пираноптеринами. Фрагмент пираноптерина играет ключевую роль в свойствах металлического сайта в группе одноядерных ферментов молибдена с различными функциями: координация; стабилизация и модуляция окислительно-восстановительных переходов центра, выступающего в качестве окислительно-восстановительного буфера; для 
окислительно-восстановительного

различных каталитических реакциях. Координационная сфера металла снабжена атомами кислорода и/или серы, селена в различных формах. Вольфрам является антагонистом молибдена и ингибирует молибдоферменты.

В текущем обзоре мы подробно рассмотрели различные исследования, касающиеся молибдена и вольфрама, механизма их поглощения, основных переносчиков, а также обсудили разрушительные свойства тяжелых металлов в ответ на их концентрацию.

Ключевые слова: молибден, молибдофермент, молибденовый кофактор, вольфрам, ксантиндегидрогеназа, альдегидоксидаза. 